\title{
Rapid DMSP production by an Antarctic phytoplankton community exposed to natural surface irradiances in late spring
}

\author{
Tessa R. Vance ${ }^{1, *}$, Andrew T. Davidson ${ }^{1,2}$, Paul G. Thomson ${ }^{3}$, Maurice Levasseur ${ }^{4}$, \\ Martine Lizotte ${ }^{4}$, Mark A. J. Curran ${ }^{1,2}$, Graham B. Jones ${ }^{5}$

\begin{abstract}
${ }^{1}$ Antarctic Climate \& Ecosystems Cooperative Research Centre, University of Tasmania, Private Bag 80, Hobart, Tasmania 7001, Australia

${ }^{2}$ Australian Antarctic Division, 203 Channel Highway, Kingston, Tasmania 7050, Australia

${ }^{3}$ School of Environmental Systems Engineering \& The UWA Oceans Institute, University of Western Australia, Mailstop 470, Crawley, Western Australia 6009, Australia

${ }^{4}$ Québec-Océan, Université Laval, 1045 Avenue de la Médecine, Québec, Quebec, G1V 0A6, Canada

${ }^{5}$ Marine Ecology Research Centre, Southern Cross University, Lismore, New South Wales 2480, Australia
\end{abstract}

\begin{abstract}
Natural marine microbial communities sourced from under fast ice at an Antarctic coastal site were incubated in tanks under differently attenuated natural sunlight for $2 \mathrm{wk}$ in late spring (Expt 1) and early summer (Expt 2). In the $18 \mathrm{~d}$ period between the 2 sampling episodes, the ice edge retreated from 10 to within $1.5 \mathrm{~km}$ of the sampling site, and the fast ice began to break up. Expt 1 rapidly produced significant quantities of total DMSP $\left(\mathrm{DMSP}_{\mathrm{t}}\right)$ with concentrations increasing from $16.6 \mathrm{nmol} \mathrm{l}^{-1}$ to $192.7-204.5 \mathrm{nmol} \mathrm{l}^{-1}$ in $2 \mathrm{~d}$. We believe this is the largest observed increase in $\mathrm{DMSP}_{\mathrm{t}}$ in a semi-natural community over this time frame. Abundances of Phaeocystis antarctica increased significantly during this initial period, while other phytoplankton species/ groups remained stable. $\mathrm{DMSP}_{\mathrm{t}}$ concentrations then declined at rates averaging 39.2-50.0 nmol $\mathrm{l}^{-1} \mathrm{~d}^{-1}$ between Days 2 and 4 . No major DMSP ${ }_{\mathrm{t}}$ production event occurred during Expt 2 despite strong community similarities. Sea ice breakout exposes phytoplankton to significant light-related oxidative stress, and these results suggest the rapid production of $\mathrm{DMSP}_{\mathrm{t}}$ during Expt 1 was due to the initiation of anti-oxidant mechanisms by a low-light-acclimated community in response to solar radiation stress. DMS concentrations remained comparatively low throughout Expt 1, suggesting oxidation of DMSP to products other than DMS. Rapid sea ice breakout in coastal regions of Antarctica may result in similar fast DMSP production events during spring.
\end{abstract}

KEY WORDS: DMSP · Light stress · Antarctica $\cdot$ Phaeocystis antarctica

Resale or republication not permitted without written consent of the publisher

\section{INTRODUCTION}

DMS emitted from marine microbial communities is implicated in aerosol seeding of clouds, as DMS is a source of cloud condensation nuclei (CCN) (Andreae \& Crutzen 1997). In remote marine areas, the production of DMS has been suggested to be a selfregulating feedback, with any increase in emissions leading to increased cloud cover, subsequently reducing the light and/or temperature to which the phytoplankton communities responsible for DMS production are exposed (Bates et al. 1987, Charlson et al. 1987). Evidence to support this hypothesis has proven elusive (Quinn \& Bates 2011), and finding a link between DMS emissions and CCN is likely to be complicated by large regional variability in the sensi- 
tivity of CCN production per unit mass of sulphur emitted (Woodhouse et al. 2013). However, the cycling of DMS and its related compounds is still of major interest considering its importance in the global sulfur cycle and its numerous physiological and ecological roles in the ocean. DMS is intensively cycled by numerous microbial and photochemical processes in seawater that primarily determine the amount of DMS available for atmospheric flux (Stefels et al. 2007). While at the broad scale DMS dynamics are suggested to be light dependent, in field studies it is becoming increasingly clear that there is frequently a large spatiotemporal disparity between DMS and DMSP distributions (e.g. Vallina \& Simo 2007, Lizotte et al. 2012). Furthermore, the link between solar radiation dose and DMS concentrations can be quite weak depending on the time scale viewed and the geographical region examined (Derevianko et al. 2009; Belviso \& Caniaux 2009). Nonetheless, numerous laboratory and field studies now clearly suggest a significant correlation between DMS concentrations and exposure to natural sunlight (e.g. Toole et al. 2006, Galí et al. 2011, Lizotte et al. 2012).

Polar waters have the most seasonally variable light climate on earth (Delille 2004). Extreme variations in surface sunlight at high latitudes are further exacerbated by the ephemeral nature of sea ice, which in the Southern Ocean retreats by around $10^{\circ}$ of latitude southward in spring and summer (Thomas \& Dieckmann 2002). Beneath sea ice, phytoplankton subsist on as little as $0.1-0.9 \%$ of surface radiation by having photosystems acclimated to low light, an adaptation particularly necessary in spring when surface melting and brine inclusions in sea ice increasingly scatter and absorb light. However, once lowlight acclimated, a photosystem can be saturated by comparatively low irradiances (e.g. $25 \mu \mathrm{mol}$ photons $\mathrm{m}^{-2} \mathrm{~s}^{-1}$ ), leaving sub-ice phytoplankton susceptible to even small increases in radiation (SooHoo et al. 1987, Thomas \& Dieckmann 2002).

In spring, sea ice breakout floods surface seawater in the seasonal ice zone (SIZ), with incident radiation as high as $1100 \mu \mathrm{mol}$ photons $\mathrm{m}^{-2} \mathrm{~s}^{-1}$, often over time periods too short for photo-acclimation (Trodahl \& Buckley 1989, Helbling et al. 1994, Kirst \& Weincke 1995, Thomas \& Dieckmann 2002). Fast ice breakout can be similarly rapid; in East Antarctica during spring, fast ice often breaks out within a $24 \mathrm{~h}$ period due to intense cyclonic activity (Heil 2006), exposing marine microbial communities to surface irradiances within hours (Gibson et al. 1997). Such rapid increases in solar radiation saturate the photosynthetic apparatus and produce damaging reactive oxygen species (ROS). ROS production triggers the synthesis of anti-oxidants by the phytoplankton to inactivate the ROS (Vincent \& Roy 1993, Niyogi 1999). DMSP and DMS are highly effective cellular scavengers of ROS, and their production in specific phytoplankton species has been shown to increase under environmental stress such as exposure to UV radiation (Sunda et al. 2002). In the Antarctic SIZ, observations of exceptionally high concentrations and turnover rates of DMS, DMSP and DMSO led Asher et al. (2011) to suggest that rapid redox cycling between DMS and DMSO plays an important role in photoprotection.

The goal of this study was to investigate how an abrupt increase in irradiance mimicking the rapid changes in light conditions found at the marginal ice zone during the declining sea ice season affects DMSP and DMS production. Two consecutive minicosm incubations were performed, timed to capture the end of spring and early summer ice conditions. We compare the results from the 2 incubations, which had very similar phytoplankton assemblages but vastly different DMSP production regimes.

\section{MATERIALS AND METHODS}

\section{Light treatments, light measurements and minicosm setup}

Seawater was $200 \mu \mathrm{m}$ screened to exclude large zooplankton and pumped from under the fast ice $60 \mathrm{~m}$ offshore from Davis station, East Antarctica $\left(68^{\circ} 35^{\prime} \mathrm{S}, 77^{\circ} 58^{\prime} \mathrm{E}\right)$ into four $650 \mathrm{l}$ tanks exposed to ambient sunlight. The tanks were filled simultaneously to ensure the same representative community in each tank. The pump and plumbing were lined with Teflon to minimize contamination of the water. After filling, the tanks were allowed to equilibrate in the dark for 12-15 h, before being closed and exposed to ambient sunlight differentially attenuated by filters (see later in this section). The tanks were housed in a modified refrigerated shipping container to ensure that the communities were maintained at in situ ambient temperatures $(0.97 \pm 0.78$ and $1.32 \pm$ $0.84^{\circ} \mathrm{C}$ for Expts 1 and 2, respectively). A basal paddle rotating at $3 \mathrm{rpm}$ gently mixed the contents. While not gas-tight, the tanks were semi-sealed, reducing gas exchange and ventilation. Expt 1 started in late spring (26 November 2002); Expt 2 started in early summer (14 December 2002).

Erythemally weighted UV and photosynthetically active radiation (PAR) were measured on the roof of 
the shipping container using a Solar Light Company 501A Biometer and a LI-COR LI-190SA Quantum sensor, and logged as $10 \mathrm{~min}$ averages. UV-transmissive acrylic domes and reflective tubes (with $>96 \%$ incident full-spectrum light reflectance) transmitted 85-95\% of ambient sunlight to the top of the tanks. Secondary screens at the top of the tanks, with transmittance measured using a GBC 916 UV/VIS spectrophotometer, attenuated the incoming radiation into different light climates (explained below). The rooftop measurements, as well as measurements taken from immediately below the water surface in one of the tanks (using clear Antarctic seawater), were modeled to obtain the light climates of each treatment (Fig. 1). Equivalent depths were calculated for each treatment based on irradiance received using Beer's Law and an attenuation coefficient for erythemal UV of 0.4 (Davidson \& van der Heijden 2000). The equivalent depths indicate the depth at which the attenuation of erythemal UV by the screens was equivalent to that in the water column of ice-edge Antarctic seawater of low turbidity (Davidson \& van der Heijden 2000). The model also accounted for varying solar zenith angle and attenuation due to the dome, reflective tubing, treatment screen, water depth and chlorophyll biomass (see Thomson et al. 2008 for further details). PAR did not differ significantly between the UV treatments as the UV-attenuating screens had minimal attenuation at visible wavelengths (Fig. 1). The spectral irradiances from the 10 min rooftop measurements (see Thomson et al. 2008) were also modeled to produce a cumulative erythemally weighted UVB dose for each treatment. Erythemal radiance is similar to plant and DNA action spectra, and is easily cross-calibrated with biometer data (Nunez et al. 2006). Final cumula-

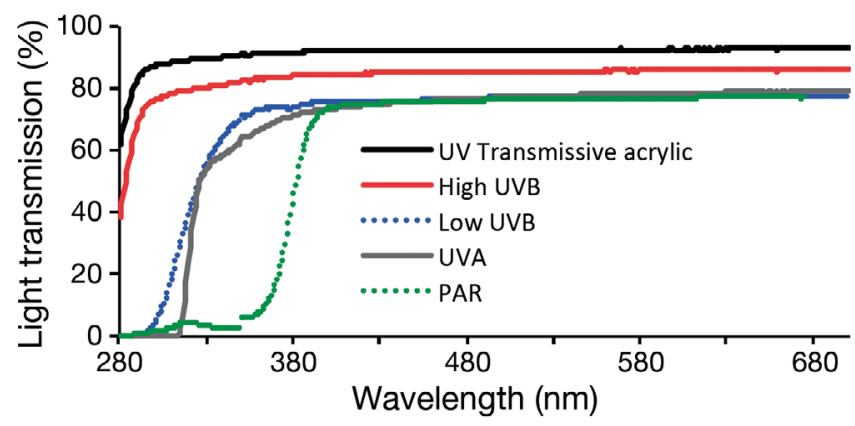

Fig. 1. Percentage transmission of ambient light to each of the 4 minicosm tanks after passing through both the UVtransmissive acrylic roof domes and the different screens (see 'Materials and methods') for each light treatment. All screening materials displayed minimal attenuation at visible wavelengths. PAR: photosynthetically active radiation tive erythemal UV doses between the 2 experiments were generally similar (Table 1).

The screens produced a different light climate in each tank (Fig. 1). Two tanks were spectral reduction treatments - a PAR-only tank (polycarbonate screen, $>385 \mathrm{~nm}$ transmittance, hereafter referred to as the 'PAR' treatment) and a PAR + UVA radiation tank (mylar screen, >315 nm transmittance, hereafter 'UVA'). A further 2 tanks received the full solar spectrum, but different screens attenuated the incoming radiation to a low-UVB (9 $\mathrm{mm}$ borosilicate glass screen, >280 nm transmittance, hereafter 'L-UVB') and a high-UVB (UV-transmissive acrylic screen, $>280 \mathrm{~nm}$ transmittance, hereafter 'H-UVB') treatment. The treatments corresponded to 12.24, 9.43, 7.15 and $4.43 \mathrm{~m}$ depth in the water column (PAR, UVA, L-UVB and H-UVB, respectively) (Thomson et al. 2008).

\section{DMS and DMSP analyses}

DMS and DMSP samples were collected in triplicate from each minicosm tank at each sample time using a Teflon sample line, stored in the dark and stabilized within $1 \mathrm{~h}$ of collection. DMS was gently purged from freshly collected samples and adsorbed onto gold tubes using analytical grade helium in an adaptation of the methods of Ayers et al. (1991) and Andreae (1993) until later analysis (Curran et al. 1998, Curran \& Jones 2000). Total DMSP (DMSP $\left.{ }_{t}\right)$ samples were stabilized using concentrated analytical grade hydrochloric acid to $\mathrm{pH} \leq 2$ as quickly as possible after collection to minimize post-collection changes and stored until analysis (Curran et al. 1998). Both DMS and DMSP ${ }_{t}$ samples were analysed using a cryogenic helium purge and trap system fitted to a 6-port switching valve, which quantitatively injected the trapped DMS into a Varian GC (gas chromatograph) equipped with a flame photometric detector and Porapak Q (Alltech) Teflon column

Table 1. Cumulative erythemally weighted UV doses $\left(\mathrm{J} \mathrm{m}^{-2}\right)$ during both experiments. UV doses were approximately linear in both experiments and each treatment received an approximately similar dose between experiments

\begin{tabular}{|lcc|}
\hline Treatment & $\begin{array}{c}\text { Expt 1 } \\
\text { (14 d exposure) }\end{array}$ & $\begin{array}{c}\text { Expt 2 } \\
\text { (13 d exposure) }\end{array}$ \\
\hline PAR & 83 & 89 \\
PAR+UVA & 258 & 274 \\
PAR+UVA+L-UVB & 633 & 678 \\
PAR+UVA+H-UVB & 1864 & 2003 \\
\hline
\end{tabular}


(1/8 inch OD). The DMS stored in the gold tubes was released using a gas-tight furnace system. $\mathrm{DMSP}_{\mathrm{t}}$ samples were quantitatively cleaved to DMS using concentrated $\mathrm{NaOH}$ immediately prior to analysis. The DMS was detected via peak area compared against the linear regression of multiple daily calibration runs of 6 known standards before conversion to $\mathrm{nmol} \mathrm{l}^{-1}$. Multiple calibration runs were performed each day $(>2)$ to check the linearity, accuracy and precision of the detector response. Detection limits were calculated on the basis of a set lowest detectable concentration (1.5 $\mathrm{ng} \mathrm{l}^{-1}$ or $0.05 \mathrm{nmol} \mathrm{l}^{-1} \mathrm{~S}$ ).

Work undertaken more recently than the analyses described here has shown that the acidification preservation step may result in an underestimation of $\mathrm{DMSP}_{\mathrm{t}}$ in samples containing colonial Phaeocystis antarctica-rich communities due to initial lyaserelated losses (del Valle et al. 2011). We observed solitary $P$. antarctica cells in our experiments rather than colonies, and therefore assume no underestimation of $\mathrm{DMSP}_{\mathrm{t}}$ concentrations due to lyase-related losses.

\section{Microbial abundance, biomass and production}

Seawater for microbial analysis was transferred from each minicosm into MilliQ-rinsed, black polythene carboys via a Teflon sample line. The black carboys were stored in the dark at $4^{\circ} \mathrm{C}$ until they were subsampled for counting and identification. Cell counts and bacterial concentrations were determined using microscopy and flow cytometry. Protists were identified and counted using a Zeiss Axiovert microscope with Nomarski interference optics. For the identification of microheterotrophs, fresh subsamples of up to $1 \mathrm{l}$ were concentrated over $47 \mathrm{~mm}$, $0.8 \mu \mathrm{m}$ polycarbonate filters as soon as possible after collection $(<4 \mathrm{~h})$. After re-suspension, cells were immediately observed at $400 \times$ magnification under Nomarski optics and blue epifluorescence (filter set 487909 with 450 to $490 \mathrm{~nm}$ exciter filter, 510 chromatic beam splitter and $520 \mathrm{~nm}$ barrier filter) using a Zeiss Axiovert inverted microscope. The trophic status of the cells was determined based on the presence or absence of chlorophyll. A further subsample of approximately $960 \mathrm{ml}$ was fixed with $1 \%$ final concentration EM grade glutaraldehyde for $20 \mathrm{~min}$ and then post-fixed with approximately $2 \mathrm{ml} \mathrm{l}^{-1}$ of acid Lugol's iodine. After $\geq 4 \mathrm{~d}$ settlement, the supernatant was removed by aspiration and the samples were stored at $4 \pm 2^{\circ} \mathrm{C}$ and analyzed within 6 mo. An aliquot of concentrate was transferred to Utermöhl sedimentation cylinders and the cells in 20 random fields were counted and identified. Information from epifluorescent microscopy and transmission electron microscopy grids aided in the identification of protists (Thomson et al. 2008).

Particulate organic carbon (POC) samples were collected by filtration within $1 \mathrm{~h}$ of water collection and frozen prior to analysis. POC was measured using a Carlo Erba Elemental Analyser after removal of inorganic carbon by desiccation. See Thomson et al. (2008) for detailed methods regarding POC analysis. The cell-specific contribution of Phaeocystis antarctica to POC was calculated using the average cell biovolume of $P$. antarctica, assuming the cell was spherical and using the volume-specific carbon conversions of Menden-Deuer \& Lessard (2000).

Bacterial abundances were determined by epifluorescent microscopy during Expt 1 and flow cytometry during Expt 2. For Expt 1, bacteria were stained using DAPI; we used $0.02 \mathrm{ml} \mathrm{ml}^{-1}$ sample of $100 \mathrm{mg} \mathrm{l}^{-1}$ DAPI. The sample was allowed to stain for $15 \mathrm{~min}$ in the dark, and then it was filtered onto $25 \mathrm{~mm}, 0.2 \mu \mathrm{m}$ black polycarbonate membrane filters (Poretics) and observed at $1000 \times$ magnification on a Zeiss Axiovert under UV excitation (filter set 487902 with 365 nm exciter filter, $395 \mathrm{~nm}$ chromatic beam splitter and $420 \mathrm{~nm}$ barrier filter). For Expt 2, flow cytometry (Becton Dickinson FACScan) was used to determine total bacterial abundance after staining with SYTO 13 (Molecular Probes) to a final concentration of $2.5 \mu \mathrm{mol}$ $1^{-1}$ (Servais et al. 1999, Lebaron et al. 1998). Stained bacteria were identified in a bivariate plot of forward scatter against green fluorescence. The cytometer vials were weighed to $\pm 10^{-4} \mathrm{~g}$ before and after analysis to determine bacteria concentrations. Groundtruthing of the microscopy data against the flow cytometry data was conducted at the end of Expt 1 to ensure agreement between concentrations of total bacteria using both methods. Comparison by $t$-test showed that concentrations obtained using the 2 methods did not differ significantly (data not shown).

Chlorophyll a (chl a) concentrations were measured by HPLC (Wright et al. 1996). A known volume of water (variable depending on biomass loading) was filtered to dryness through a $13 \mathrm{~mm}$ Whatman GF/F filter ( $0.7 \mu \mathrm{m}$ nominal pore size) and frozen in liquid $\mathrm{N}_{2}$. Chl a was analysed by detection at $665 \mathrm{~nm}$ and quantified using an internal standard, trans-Bapo-8'-carotenal (Fluka) at $140 \mathrm{ng}$ per sample. The samples were identified by comparison with a standard mixture containing chl a (Jeffrey 1997, Trevena \& Jones 2006). 
Bacterial production was determined using the method of Bell (1993). $\left[{ }^{3} \mathrm{H}\right]$ thymidine saturation experiments were conducted in November 2002 and January 2003 to determine the concentration of $\left[{ }^{3} \mathrm{H}\right]$ thymidine needed for the bacterial production analyses. These tests showed saturation of $\left[{ }^{3} \mathrm{H}\right]$ thymidine availability by a concentration of $30 \mathrm{nmol} \mathrm{l}^{-1}$. The activity of samples was measured using a Beckman LS6500 liquid scintillation counter. Rates of bacterial production were calculated from the rates of thymidine incorporation. The conversion statistics applied were calculated, and were the same as those used at this study site by Pearce et al. (2007), namely $1.91 \times 10^{18}$ cells mol$^{-1}$ thymidine, a mean bacterial cell volume of $0.13{\mu \mathrm{m}^{3}}^{3}$ and a carbon content of $20 \mathrm{fg}$ $\mathrm{C} \mathrm{cell}^{-1}$. Due to equipment and personnel constraints during the field season, we were only able to produce initial $\left(\mathrm{d}_{0}\right)$ and final $\left(\mathrm{d}_{14}\right)$ estimates of bacterial production in both experiments.

\section{RESULTS}

\section{Experiment 1}

\section{$\mathrm{DMSP}_{\mathrm{t}}$ and DMS concentrations}

Expt 1 was characterized by a spectacular but transient increase in $\mathrm{DMSP}_{\mathrm{t}}$ in the first $2 \mathrm{~d}$ of exposure (Fig. 2). DMSP ${ }_{t}$ increased rapidly in all treatments, from an initial $\left(\mathrm{d}_{0}\right)$ concentration of $16.6 \mathrm{nmol} \mathrm{l}^{-1}$, reaching maximum values of 197.8 (PAR), 204.5 (UVA), 192.7 (L-UVB) and 194.1 (H-UVB) nmol $\mathrm{l}^{-1}$ by sample day $2\left(\mathrm{~d}_{2}\right)$. DMSP $\mathrm{t}_{\mathrm{t}}$ concentrations reached higher values earlier $\left(\mathrm{d}_{1}\right)$ in the treatments with UVB radiation $\left(152.5-168.6 \mathrm{nmol} \mathrm{l}^{-1}\right)$ than in the treatments that excluded UVB radiation (102.5-103.3 nmol $\mathrm{l}^{-1}$ ). DMSP $\mathrm{t}_{\mathrm{t}}$ concentrations then declined over the next $5 \mathrm{~d}$ until $\mathrm{d}_{7}$, falling to between $47.5 \mathrm{nmol} \mathrm{l}^{-1}$ (PAR) and 60.1-61.9 $\mathrm{nmol} \mathrm{l}^{-1}$ (remaining 3 treatments). Net DMS concentrations in Expt 1 remained comparatively low and constant relative to the DMSP $_{t}$ concentrations, with mean concentrations averaging $8.8 \mathrm{nmol}^{-1}$ (Fig. 2). Ventilation of DMS in both experiments as a loss process would have been minimal due to the semi-sealed nature of the tanks.

Microbial abundance

Autotrophic and heterotrophic species from each treatment at each sample point were counted in both experiments, and the most abundant species, total
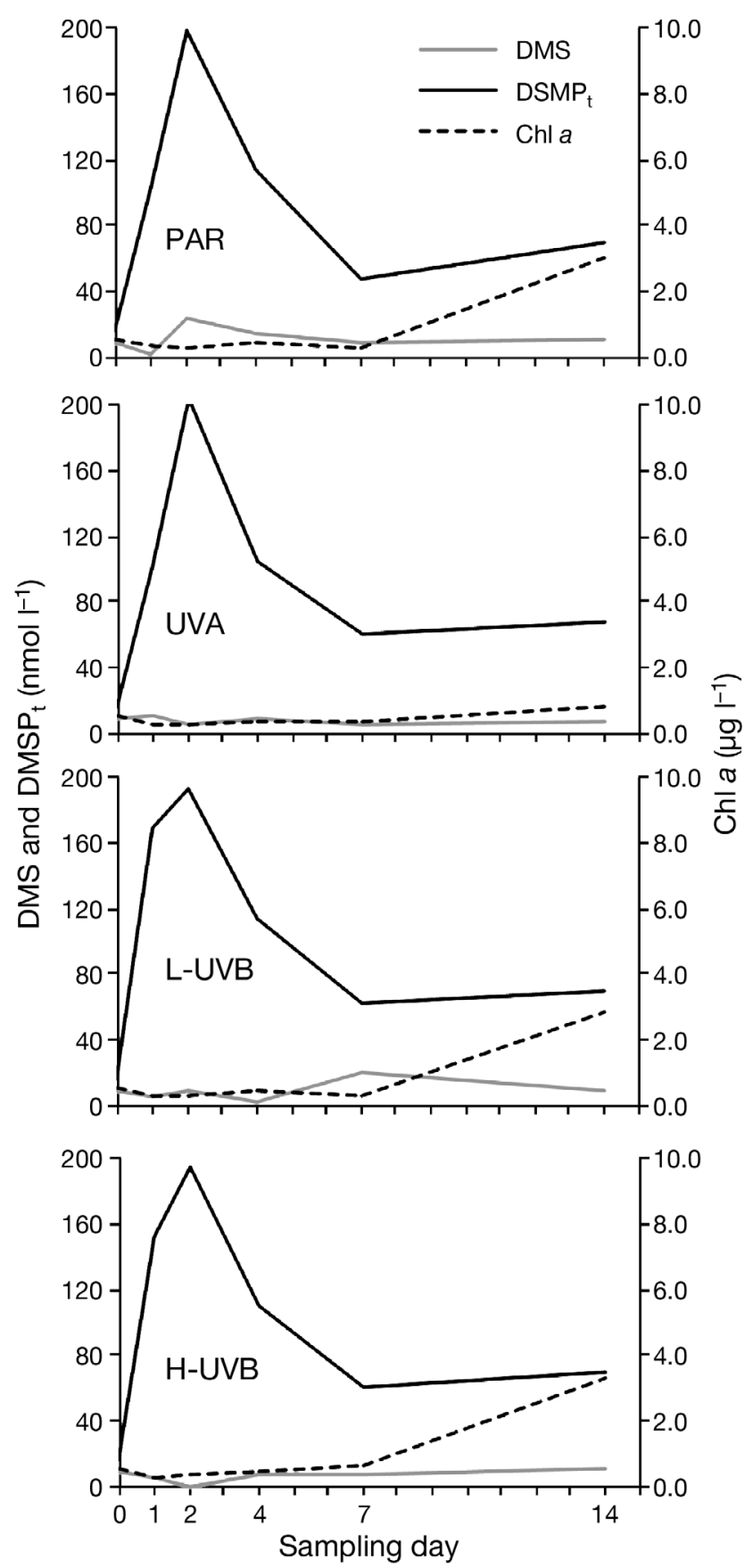

Fig. 2. Total DMSP (DMSP ${ }_{t}$ black), DMS (grey) and chlorophyll a (chl $a_{\text {; }}$ dashed line) concentrations from each treatment (PAR, UVA, L-UVB and H-UVB) in Expt 1 (late spring). Sampling day is indicated on the $x$-axis. Standard errors of the mean (from triplicate sample analyses) averaged \pm 8.29 $\mathrm{nmol} \mathrm{l}^{-1}$ DMSP $_{\mathrm{t}}$ (range: $1.30-54.73 \mathrm{nmol} \mathrm{l}^{-1}$ ) and $\pm 3.22 \mathrm{nmol}$ $\mathrm{l}^{-1}$ DMS (range: $0.10-10.6 \mathrm{nmol} \mathrm{l}^{-1}$ )

bacteria and chl a are shown in Tables $2 \& 3$. The dominant species were Phaeocystis antarctica, Pyramimonas gelidicola, an unidentified cryptophyte 


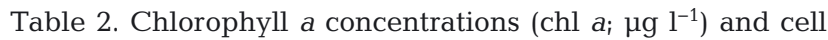
counts of the 6 most abundant species/groups and total bacteria during Expt $1\left(10^{5}\right.$ cells $1^{-1}$ for protists and $10^{8}$ cells $l^{-1}$ for bacteria). Species/groups that increased significantly (an increase above the SEM) in the first 1-2 d of exposure are shown in bold. Auto dino: autotrophic dinoflagellates as described in the text; crypto 1: unidentified cryptophyte species; $<5$ flag: $<5 \mu \mathrm{m}$ flagellate species; $<10 \mu \mathrm{m}$ het flag: heterotrophic flagellates $<10 \mu \mathrm{m}$

\begin{tabular}{|lcccccc|}
\hline Treatment & $\mathrm{d}_{0}$ & $\mathrm{~d}_{1}$ & $\mathrm{~d}_{2}$ & $\mathrm{~d}_{4}$ & $\mathrm{~d}_{7}$ & $\mathrm{~d}_{14}$ \\
\hline PAR & & & & & & \\
Phaeocystis antarctica & $\mathbf{0 . 5}$ & $\mathbf{0 . 8}$ & $\mathbf{1 . 7}$ & $\mathbf{1 . 9}$ & $\mathbf{3 . 7}$ & $\mathbf{6 . 1}$ \\
Auto dino & 0.1 & 0.1 & 0.2 & 0.1 & 0.4 & 0.4 \\
Pyramimonas gelidicola & 0.3 & 0.3 & 0.2 & 1.1 & 0.2 & 10.3 \\
Crypto 1 & 0.5 & 0.4 & 0.4 & 1.5 & 1.9 & 14.1 \\
<5 Flag & $\mathbf{3 . 6}$ & $\mathbf{5 . 2}$ & $\mathbf{6 . 5}$ & $\mathbf{4 . 7}$ & $\mathbf{2 . 7}$ & $\mathbf{3 . 6}$ \\
<10 Het fl & 0.4 & 0.4 & 0.1 & 3.0 & 1.5 & 2.0 \\
Chl a & 0.54 & 0.36 & 0.30 & 0.43 & 0.32 & 3.04 \\
Total bacteria & $\mathbf{2 . 3}$ & $\mathbf{3 . 1}$ & $\mathbf{2 . 2}$ & $\mathbf{2 . 3}$ & $\mathbf{2 . 4}$ & $\mathbf{1 0 . 0}$ \\
UVA & & & & & & \\
P. antarctica & $\mathbf{0 . 5}$ & $\mathbf{7 . 0}$ & $\mathbf{5 . 6}$ & $\mathbf{2 . 2}$ & $\mathbf{1 . 8}$ & $\mathbf{7 . 4}$ \\
Auto dino & 0.1 & 0.1 & 0.2 & 0.1 & $<0.1$ & $<0.1$ \\
P. gelidicola & 0.3 & 0.3 & 0.9 & 0.9 & 0.3 & 3.2 \\
Crypto 1 & 0.5 & 0.4 & 1.4 & 0.9 & 1.6 & 2.9 \\
< 5 Flag & $\mathbf{3 . 6}$ & $\mathbf{5 . 2}$ & $\mathbf{2 . 0}$ & $\mathbf{1 . 3}$ & $\mathbf{0 . 3}$ & $\mathbf{0 . 8}$ \\
<10 Het flag & 0.4 & 0.4 & 0.4 & 0.6 & 0.2 & 1.8 \\
Chl a & 0.54 & 0.28 & 0.29 & 0.33 & 0.33 & 0.86 \\
Total bacteria & 2.3 & 2.5 & 1.8 & 2.0 & 2.2 & 12.4 \\
L-UVB & & & & & & \\
P. antarctica & $\mathbf{0 . 5}$ & $\mathbf{1 . 4}$ & $\mathbf{1 . 2}$ & $\mathbf{2 . 7}$ & $\mathbf{6 . 3}$ & $\mathbf{1 9 . 4}$ \\
Auto dino & 0.1 & $<0.1$ & $<0.1$ & 0.2 & $<0.1$ & 0.4 \\
P. gelidicola & 0.3 & 0.2 & 0.2 & 0.5 & $<0.1$ & 6.2 \\
Crypto 1 & 0.5 & 0.3 & 0.3 & 0.9 & 3.6 & 8.6 \\
<5 Flag & 3.6 & 0.4 & 0.3 & 0.6 & 1.7 & 3.9 \\
<10 Het flag & 0.4 & 0.1 & 0.1 & 0.7 & 0.8 & 4.4 \\
Chl a & 0.54 & 0.32 & 0.31 & 0.42 & 0.32 & 2.87 \\
Total bacteria & $\mathbf{2 . 3}$ & $\mathbf{3 . 3}$ & $\mathbf{1 . 9}$ & $\mathbf{2 . 1}$ & $\mathbf{1 . 8}$ & $\mathbf{1 3 . 6}$ \\
H-UVB & & & & & & \\
P. antarctica & $\mathbf{0 . 5}$ & $\mathbf{1 . 3}$ & $\mathbf{4 . 5}$ & $\mathbf{2 . 8}$ & $\mathbf{4 . 0}$ & $\mathbf{1 1 . 2}$ \\
Auto dino & 0.1 & $<0.1$ & 0.3 & 0.1 & 0.1 & $<0.1$ \\
P. gelidicola & 0.3 & 0.1 & 0.6 & 0.4 & 1.4 & 6.3 \\
Crypto 1 & 0.5 & 0.3 & 0.6 & 0.4 & 2.2 & 9.7 \\
<5 Flag & 3.6 & 1.3 & 2.1 & 1.9 & 2.2 & 3.2 \\
<10 Het flag & $\mathbf{0 . 4}$ & $\mathbf{0 . 8}$ & $\mathbf{0 . 8}$ & $\mathbf{2 . 0}$ & $\mathbf{2 . 2}$ & $\mathbf{3 . 1}$ \\
Chl a & 0.54 & 0.26 & 0.39 & 0.44 & 0.64 & 3.29 \\
Total bacteria & 2.3 & 2.0 & 1.8 & 1.2 & 1.8 & 10.9 \\
\hline
\end{tabular}

species (hereafter cyptophyte 1) and 3 combined groups: $<5 \mu \mathrm{m}$ flagellates, $<10 \mu \mathrm{m}$ heterotrophic flagellates and autotrophic dinoflagellates (which consisted of 2 species of Gymnodinium between 10 and $20 \mu \mathrm{m}$ and the brine dinoflagellate Polarella glacialis). For details on less abundant species, see Thomson et al. (2008).

During the initial days of Expt 1 there was a general decline in the concentrations of abundant phytoplankton groups, coinciding with a small decline in chl a concentrations (which were initially low, at $0.54 \mu \mathrm{g}$
Table 3. Chlorophyll a concentrations and cell counts of the 6 most abundant species/groups and total bacteria during Expt $2\left(10^{5}\right.$ cells $1^{-1}$ for protists and $10^{8}$ cells $l^{-1}$ for bacteria $)$. Species/groups as for Table 2 (Expt 1), except auto dino also includes an unidentified $10 \mu \mathrm{m}$ autotrophic Gymnodinium species. Significant increases $\left(\mathrm{d}_{0}-\mathrm{d}_{2}\right)$ are shown in bold except for total bacteria, as significance or otherwise of increases could not be assessed from the flow cytometry counts

\begin{tabular}{|lcccccc}
\hline Treatment & $\mathrm{d}_{0}$ & $\mathrm{~d}_{1}$ & $\mathrm{~d}_{2}$ & $\mathrm{~d}_{4}$ & $\mathrm{~d}_{7}$ & $\mathrm{~d}_{13}$ \\
\hline PAR & & & & & & \\
Phaeocystis antarctica & 1.3 & 1.6 & 0.4 & 0.5 & 0.9 & 5.8 \\
Auto dino & 2.9 & 2.3 & 1.5 & 0.6 & 3.0 & 27.2 \\
Pyramimonas gelidicola & 0.7 & 0.3 & 0.4 & 0.1 & 1.0 & 4.2 \\
Crypto 1 & 20.8 & 10.5 & 6.5 & 5.6 & 19.6 & 85.5 \\
<5 Flag & 5.9 & 4.5 & 2.4 & 1.3 & 10.0 & 44.3 \\
<10 Het flag & $\mathbf{0 . 8}$ & $\mathbf{3 . 3}$ & $\mathbf{0 . 5}$ & $\mathbf{0 . 5}$ & $\mathbf{1 . 4}$ & $\mathbf{2 . 7}$ \\
Chl a & 0.38 & 0.49 & 0.54 & 0.94 & 2.27 & 6.09 \\
Total bacteria & 4.3 & 2.6 & 6.5 & 7.6 & 4.8 & 1.0 \\
UVA & & & & & & \\
P. antarctica & 1.3 & 1.6 & 0.8 & 0.4 & 0.7 & 5.9 \\
Auto dino & 2.9 & 1.7 & 0.6 & 0.6 & 1.6 & 30.1 \\
P. gelidicola & 0.7 & 0.5 & $<0.1$ & 0.1 & 0.3 & 9.0 \\
Crypto 1 & 20.8 & 13.3 & 3.8 & 3.7 & 8.5 & 146.5 \\
<5 Flag & 5.9 & 5.5 & 1.1 & 2.0 & 5.5 & 59.4 \\
<10 Het flag & $\mathbf{0 . 8}$ & $\mathbf{2 . 0}$ & $\mathbf{0 . 9}$ & $\mathbf{0 . 6}$ & $\mathbf{1 . 3}$ & $\mathbf{3 . 5}$ \\
Chl a & 0.38 & 0.52 & 0.53 & 1.16 & 1.25 & 7.02 \\
Total bacteria & 4.3 & 4.6 & 5.0 & 10.9 & 3.9 & 1.4 \\
L-UVB & & & & & & \\
P. antarctica & 1.3 & 1.6 & 0.8 & 0.8 & 1.0 & 10.2 \\
Auto dino & 2.9 & 3.4 & 0.2 & 2.7 & 2.2 & 38.7 \\
P. gelidicola & 0.7 & 0.2 & $\mathrm{nd}$ & 0.2 & 0.3 & 6.5 \\
Crypto 1 & 20.8 & 14.3 & 2.2 & 8.5 & 9.8 & 13.0 \\
< F Flag & $\mathbf{5 . 9}$ & $\mathbf{7 . 8}$ & $\mathbf{0 . 8}$ & $\mathbf{4 . 2}$ & $\mathbf{4 . 7}$ & $\mathbf{6 8 . 3}$ \\
<10 Het flag & 0.8 & 0.9 & 0.8 & 1.0 & 0.8 & 3.3 \\
Chl a & 0.38 & 0.52 & 0.54 & 0.87 & 1.89 & 7.55 \\
Total bacteria & 4.3 & 5.2 & 5.8 & 10.3 & 4.7 & 1.0 \\
H-UVB & & & & & & \\
P. antarctica & 1.3 & 0.7 & 0.2 & 0.5 & 1.4 & 11.5 \\
Auto dino & $\mathbf{2 . 9}$ & $\mathbf{4 . 3}$ & $\mathbf{1 . 0}$ & $\mathbf{0 . 9}$ & $\mathbf{1 . 7}$ & $\mathbf{5 . 6}$ \\
P. gelidicola & 0.7 & 0.6 & 0.3 & 0.7 & 0.8 & 2.7 \\
Crypto 1 & 20.8 & 17.4 & 5.8 & 10.5 & 12.4 & 72.5 \\
<5 Flag & $\mathbf{5 . 9}$ & $\mathbf{9 . 2}$ & $\mathbf{3 . 1}$ & $\mathbf{4 . 0}$ & $\mathbf{5 . 5}$ & $\mathbf{1 3 . 8}$ \\
<10 Het. flag & 0.8 & 0.5 & 0.5 & 0.8 & 1.3 & 10.2 \\
Chl a & 0.38 & 0.61 & 0.61 & 1.05 & 2.52 & 6.82 \\
Total bacteria & 4.3 & 6.0 & 5.1 & 9.5 & 3.2 & 0.8 \\
\hline
\end{tabular}

$\mathrm{I}^{-1}$; Table 2). Concentrations of autotrophic dinoflagellates (potential DMSP producers) remained low

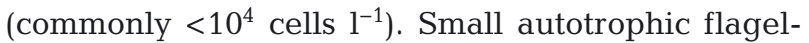
lates $(<5 \mu \mathrm{m})$ increased significantly by $\mathrm{d}_{1}$ in the PAR and UVA treatments, but not in the UVB-exposed treatments. The concentrations of $<10 \mu \mathrm{m}$ heterotrophic flagellates increased marginally in the H-UVB treatment, but not elsewhere. In contrast, concentrations of Phaeocystis antarctica, a high DMSP-producing prymnesiophyte common to Antarctic and Southern Ocean waters (Gibson et al. 1990, Davidson \& 
Marchant 1992 and references therein, Tang et al. 2009) increased significantly in all treatments in the first 1-4 d, with by far the most rapid early increase occurring in the UVA treatment (Table 2). It is noteworthy that this early increase of $P$. antarctica occurred despite Thomson et al. (2008) finding significant inhibition in this treatment at the end of the exposure period $\left(\mathrm{d}_{14}\right)$, which included inhibition of $P$. antarctica.

Concentrations of total bacteria changed little to $\mathrm{d}_{4}\left(1.2-3.3 \times 10^{8}\right.$ cells $\left.\mathrm{l}^{-1}\right)$, with only small increases in the PAR and L-UVB treatments (Table 2). Bacterial production at $\mathrm{d}_{0}$ ranged from 1.03 to

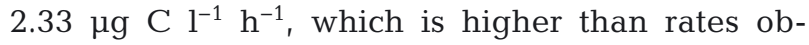
served previously at Davis station during November, though similar to rates observed during early autumn (March) (Pearce et al. 2007). Bacterial production rates at $d_{14}$ were higher than initial rates, at 5.49 (PAR), 5.08 (UVA), 8.03 (L-UVB) and 5.43

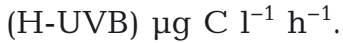

\section{Experiment 2}

\section{$\mathrm{DMSP}_{\mathrm{t}}$ and DMS concentrations}

DMSP $_{\mathrm{t}}$ concentrations during Expt 2 remained very similar between treatments. A significant and linear increase $(p<0.001)$ was observed in all treatments from $48.3 \mathrm{nmol}^{-1}$ at $\mathrm{d}_{0}$ to $70.2-73.0 \mathrm{nmol} \mathrm{l}^{-1}$ by $\mathrm{d}_{13}$ (Fig. 3). Net DMS concentrations in Expt 2 remained low throughout, with mean concentrations

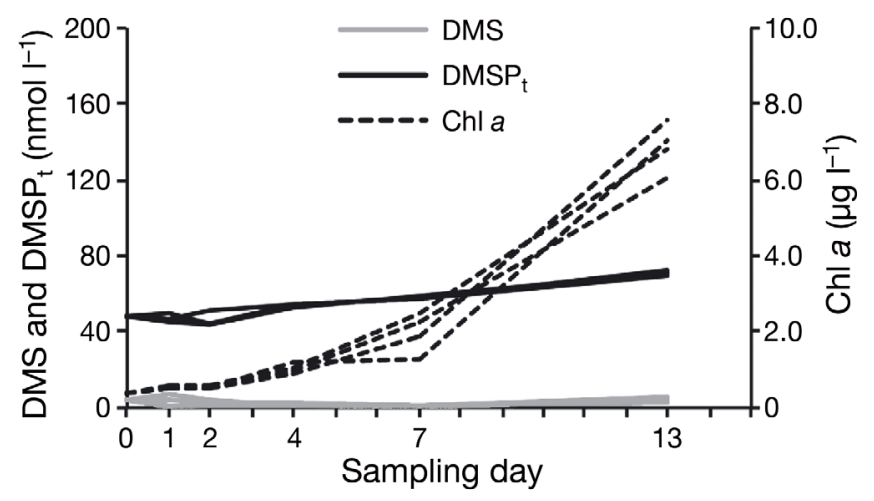

Fig. 3. Total DMSP (DMSP ${ }_{\mathrm{t}}$ black), DMS (grey) and chlorophyll a (chl $a_{\text {; }}$ dashed line) concentrations for all 4 treatments (PAR, UVA, L-UVB and H-UVB) from Expt 2 (early summer). For ease of comparison, concentrations are shown against the same $y$-axes ranges used for Fig. 2. Sampling day is indicated on the $X$-axis. Standard errors of the mean (from triplicate sample analyses) averaged $\pm 0.48 \mathrm{nmol} \mathrm{l}^{-1}$ DMSP $_{\mathrm{t}}$ (range: $0.11-1.94 \mathrm{nmol} \mathrm{l}^{-1}$ ) and $\pm 1.01 \mathrm{nmol} \mathrm{l}^{-1} \mathrm{DMS}$ (range: $0.12-2.77 \mathrm{nmol} \mathrm{l}^{-1}$ ). Note that the final sampling day for Expt 2 occurred at $13 \mathrm{~d}$ significantly lower than those from Expt 1 (8.8 and $2.8 \mathrm{nmol} \mathrm{l}^{-1}$, respectively, $\mathrm{p}<0.001$ ).

Microbial abundance

The community composition of Expt 2 was generally similar to that of Expt 1 . Notable differences were abundances that were frequently an order of magnitude higher in Expt 2, and an unidentified $10 \mu \mathrm{m}$ autotrophic Gymnodinium species was observed at abundances warranting inclusion in the autotrophic dinoflagellate group (Table 3). This group also showed higher abundances than in Expt 1 , with cell counts generally in the $10^{5}-10^{6}$ cells $^{-1}$ range, compared with the frequently $<10^{4}$ cells $1^{-1}$ found in Expt 1 (Table 3 versus Table 2). An unidentified cryptophyte species (cryptophyte 1) that showed low abundances in Expt 1 was numerically dominant initially in Expt 2. Chl a concentrations increased slightly in all but the PAR treatment in the first days of Expt 2 (in contrast to Expt 1), though abundances of most phytoplankton groups did not increase. Chl a displayed roughly exponential growth in both experiments over the full incubation period, and nutrients were not limiting in either experiment (see Fig. 4 in Thomson et al. 2008).

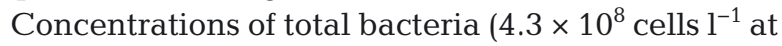
$\mathrm{d}_{0}$ ) increased initially in Expt 2 in all but the PAR treatment; however, the flow cytometry counts do not allow assessment of the significance of any increases (Table 3). Bacterial production rates dropped from a high of 6.7-10.6 $\mathrm{\mu} \mathrm{C}^{-1} \mathrm{~h}^{-1}$ at $\mathrm{d}_{0}$ to 0.5 (H-UVB), 1.5 (L-UVB), 2.1 (UVA) and 2.8 (PAR) $\mu g \mathrm{Cl}^{-1} \mathrm{~h}^{-1}$ at $\mathrm{d}_{13}$.

\section{DISCUSSION}

The 2 experiments generated very different $\mathrm{DMSP}_{t}$ temporal dynamics despite similar community assemblages. We suggest that these differences in $\mathrm{DMSP}_{t}$ dynamics were a reflection of the different light histories of the 2 communities prior to sampling. At Davis station, sea ice opacity reaches a maximum in late spring as turbidity increases due to the development of brine inclusions (Smolskaia et al. 1999). As a result, light transmittance to the water column below the sea ice surface is greatly reduced at the time when the fast ice edge is beginning to breakout and solar zenith angle is approaching its maximum.

Fast ice at Davis station can persist far longer than ice in other coastal Antarctic regions. Davis is not frequently subjected to strong winds or wave-ice inter- 
action, both of which drive the break-up of sea ice. Fast ice breakout generally occurs as a single, rapid event resulting from intermittent high winds, often as late as December-January (Heil 2006, Thomson et al. 2006). At the time of sampling for Expt 1 (late November) the ice edge was around $10 \mathrm{~km}$ from the sampling site and the fast ice was uniform and largely free of leads or cracks. Phytoplankton cells underneath the fast ice prior to the start of Expt 1 would have thus been extremely low-light acclimated. By the time of sampling for Expt 2 (midDecember), the ice edge had retreated to within $1.5 \mathrm{~km}$ of the sampling site, significant leads had formed and the fast ice had begun to break up into floes around the sample site. This would have allowed surface irradiances to penetrate to the water column beneath, contributing to the increased light tolerance of the community sampled for Expt 2 (Thomson et al. 2008).

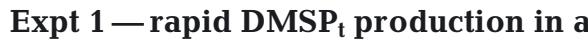 low-light-acclimated community}

The origin of the rapid increase in $\mathrm{DMSP}_{\mathrm{t}}$ production in Expt 1 was not immediately obvious and the question remains as to why such intensive $\mathrm{DMSP}_{t}$ production was necessary. The anti-oxidant hypothesis proposed by Sunda et al. (2002) may explain the rapid $\mathrm{DMSP}_{\mathrm{t}}$ production. These authors suggested that DMSP and its breakdown products DMS, acrylate, DMSO and methanesulfinic acid (MSNA) - constitute a cascading system of radical scavenging compounds that serve as an anti-oxidation mechanism for cells undergoing stress (such as exposure to UVR). This anti-oxidant process should result in declining DMSP concentrations, unless an initial upregulation in production was required before the subsequent oxidative loss (Stefels et al. 2007). This hypothesis fits with what was observed in Expt 1-a rapid increase and then decline in DMSP $_{t}$ concentrations. Sunda et al. (2002) argue that this anti-oxidation mechanism may allow DMSP producing species to be more competitive by quickly adapting to stress.

Phaeocystis antarctica showed consistently high tolerances to UVB radiation in both Expts 1 and 2, but significant inhibition of this species occurred in the UVA treatment at $d_{14}$ in Expt 1 (Thomson et al. 2008). Phaeocystis antarctica abundances increased significantly in all treatments by $\mathrm{d}_{2}$ and remained numerically dominant throughout. Interestingly, the $\mathrm{d}_{14}$ inhibition of $P$. antarctica in the UVA treatment was not obvious initially; in fact, this treatment had the highest $\mathrm{d}_{1}$ abundances of $P$. antarctica. Indeed, $P$. antarctica appeared to have a competitive advantage initially in all treatments given the general lack of significant abundance increases by other species or groups.

While the generally uniform $\mathrm{DMSP}_{\mathrm{t}}$ increases by $\mathrm{d}_{2}$ would appear to be a similar stress response across all treatments, abundances of Phaeocystis antarctica at $\mathrm{d}_{2}$ varied greatly. However, it is unlikely other species or groups contributed significantly to $\mathrm{DMSP}_{\mathrm{t}}$ production during Expt 1. Abundances of autotrophic dinoflagellates (potential DMSP producers) were around one-fifth those of $P$. antarctica at $\mathrm{d}_{0}$ and did not increase in the initial days of exposure, suggesting that their contribution to $\mathrm{DMSP}_{\mathrm{t}}$ production was minimal (Table 2). The $<5 \mu \mathrm{m}$ flagellate class increased significantly in the PAR and UVA treatments but was comprised primarily of chrysophytes, small cryptophyes and kinetoplasts, none of which are known DMSP producers. While, this suggests $P$. antarctica was primarily responsible for $\mathrm{DMSP}_{\mathrm{t}}$ production, it does not explain the varied abundances of $P$. antarctica.

To explore the treatment differences between $\mathrm{DMSP}_{\mathrm{t}}$ concentrations and Phaeocystis antarctica abundances with the data available, we assumed total and particulate DMSP concentrations were equivalent (see Kiene \& Slezak 2006) and only associated with $P$. antarctica during Expt 1 . We then calculated the ratio of $\mathrm{DMSP}_{\mathrm{t}}$ to $P$. antarctica associated carbon (DMSP $: P$. antarctica $\mathrm{C}$ ) at each sample time based on an average measured $P$. antarctica equivalent spherical diameter of $6.5 \mu \mathrm{m}$ (A. Davidson pers. comm.) and the POC values presented in Thomson et al. (2008). The estimated ratio was 4 times higher by $\mathrm{d}_{1}$ in all treatments except UVA, for which the ratio was lower than the starting ratio of $0.090 \mathrm{~mol}: \mathrm{mol}$. By $\mathrm{d}_{2}$, ratios were similar to the starting ratio in the UVA and H-UVB treatments, but were still 3-4 times higher in the PAR and L-UVB treatments. By $\mathrm{d}_{4}$, all 4 treatments showed similar ratios $(0.115-0.178 \mathrm{~mol}$ : mol) that were only slightly higher than the $\mathrm{d}_{0}$ ratio. The proportion of $\mathrm{C}$ associated with $P$. antarctica also increased in all treatments (especially the UVA and H-UVB treatments), again suggesting that $P$. antarctica was able to outcompete other phytoplankton in the initial days of exposure.

Stefels et al. (2007) collated numerous data sets to calculate an average $\mathrm{DMSP}_{\mathrm{t}}: \mathrm{C}$ ratio for haptophytes (including Phaeocystis antarctica) of $0.011 \pm 0.007$ mol:mol. Our $\mathrm{d}_{0}$ ratio is almost an order of magnitude higher than this haptophyte average, which is closer 
to what we observed in general after $d_{7}$ (when the communities had had time to acclimate to surface irradiances) and also at $d_{1}$ in the UVA treatment, suggesting rapid acclimation in this treatment. This may be due to a proportion of the $P$. antarctica cells collected for the incubation being sea ice associated, and these cells having increased production of DMSP as a cryoprotectant and osmoregulant (Kirst et al. 1991, Tang et al. 2009). The Stefels et al. (2007) average is also far lower than the ratios we observed by $\mathrm{d}_{1}$ in all but the UVA treatment, clearly showing cellular production of $\mathrm{DMSP}_{\mathrm{t}}$ far beyond the average published value.

Fig. 2 shows a large and rapid increase in $\mathrm{DMSP}_{\mathrm{t}}$ production. To investigate how much of this production was due to the hypothesized light stress effect, and how much could be associated with changing abundances of Phaeocystis antarctica, we calculated DMSP $_{t}$ 'in excess', that is, the proportion of $\mathrm{DMSP}_{\mathrm{t}}$ produced in excess of the $\mathrm{DMSP}_{\mathrm{t}}: P$. antarctica $\mathrm{C}$ ratio present at $\mathrm{d}_{0}$ (Table 4). This shows that approximately 4 times more DMSP $\mathrm{t}_{\mathrm{t}}$ than could be accounted for by changes in cell numbers was produced by $\mathrm{d}_{1}$ in all treatments except for UVA. By $\mathrm{d}_{2}$, only the PAR and L-UVB treatments were producing $\mathrm{DMSP}_{\mathrm{t}}$ greatly in excess of initial requirements. After $d_{4}$, excess DMSP $\mathrm{t}_{\mathrm{t}}$ production declined generally, and by $\mathrm{d}_{14}$ was less than before exposure to surface irradiances. Once again, it is possible that the $d_{7}$ and $d_{14}$ values from Table 4 were a more realistic representation of 'average' $\mathrm{DMSP}_{\mathrm{t}}: P$. antarctica $\mathrm{C}$ ratios for a surface-acclimated community, suggesting that the proportion of $\mathrm{DMSP}_{\mathrm{t}}$ produced in excess of abundance changes at $\mathrm{d}_{1}$ and $\mathrm{d}_{2}$ was actually much higher. If the Stefels et al. (2007) average value of $0.011 \mathrm{~mol}: \mathrm{mol}$ is used, at $\mathrm{d}_{1}$ there was $>30$ times more DMSP per cell than the average (except for the UVA treatment). However, high $\mathrm{DMSP}_{\mathrm{t}}$ 'in excess' values persisted for longer in the UVA treatment (through to $\mathrm{d}_{7}$ ). If excess DMSP $\mathrm{t}_{\mathrm{t}}$ was produced for anti-oxidation for longer in this treatment, this agrees with the find- ing of Thomson et al. (2008) that there was significant inhibition in this treatment by the end of Expt 1 (although Table 4 shows less evidence of this by $\mathrm{d}_{14}$ ).

These calculations provide more insight into $\mathrm{DMSP}_{\mathrm{t}}$ production dynamics than analysis of concentrations alone. First, the calculations indicate that that if $\mathrm{DMSP}_{\mathrm{t}}$ was produced as a stress response (assuming more DMSP is produced when cells are under greater stress), the UVA treatment was the most favourable environment initially for Phaeocystis antarctica, due to a lack of competition and/or an optimal growth environment. Second, after another $24 \mathrm{~h}\left(\mathrm{~d}_{2}\right)$, the H-UVB treatment also appeared more favourable, as abundances of $P$. antarctica increased

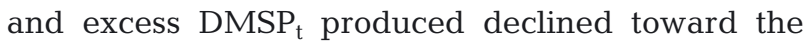
initial value. Phaeocystis antarctica produce UVabsorbing compounds (Davidson \& Marchant 1994), which may have provided protection (particularly in the UVA and H-UVB treatments) not available to other species, allowing rapid growth in a noncompetitive environment. By $\mathrm{d}_{4}$, treatment differences were minimal (Table 4). These calculations show that exposure to surface irradiances was not an impediment to the early dominance of $P$. antarctica, which adapted quickly to the irradiance received by producing excess DMSP to ameliorate the effects of light stress when required.

Stefels \& van Leeuwe (1998) calculated intracellular DMSP content to examine Phaeocystis cultures subjected to iron and (artificial) light stress. These authors reported a steady increase in intracellular DMSP concentrations in their high-light, iron-replete Phaeocystis cultures (analogous to the $\mathrm{d}_{2}$ exposed communities here) and suggested this was due to nitrogen limitation and substitution of DMSP for other nitrogenous solutes, rather than a stress response. However, nutrient limitation was not observed in any treatment of either Expt 1 or 2 in the present study (see Fig. 4 in Thomson et al. 2008), suggesting that nitrogen limitation was not a factor influencing DMSP production in Expt 1.

Table 4. DMSP $:$ Phaeocystis antarctica C ratio (mol:mol, bold), proportion of total carbon allocated to P. antarctica (as a percentage, italicized) and proportion of $\mathrm{DMSP}_{\mathrm{t}}$ in excess of cellular $P$. antarctica requirements relative to $\mathrm{d}_{0}$ (Roman type) during Expt 1. Particulate organic carbon values are given in Thomson et al. (2008). Days 7 and 14 are included for comparison with $\mathrm{d}_{0}$, assuming surface light acclimation by $\mathrm{d}_{7}$

\begin{tabular}{|lcccccc}
\hline Treatment & $\mathrm{d}_{0}$ & $\mathrm{~d}_{1}$ & $\mathrm{~d}_{2}$ & $\mathrm{~d}_{4}$ & $\mathrm{~d}_{7}$ & $\mathrm{~d}_{14}$ \\
\hline PAR & $\mathbf{0 . 0 9 0} ; 2 ; 1.0$ & $\mathbf{0 . 3 7 1} ; 3 ; 4.1$ & $\mathbf{0 . 3 4 2} ; 7 ; 3.8$ & $\mathbf{0 . 1 7 8} ; 11 ; 2.0$ & $\mathbf{0 . 0 3 8 ;} ; 5 ; 0.4$ & $\mathbf{0 . 0 3 3} 7 ; 0.4$ \\
UVA & $\mathbf{0 . 0 9 0} ; 2 ; 1.0$ & $\mathbf{0 . 0 4 3} ; 7 ; 0.5$ & $\mathbf{0 . 1 0 7} 18 ; 1.2$ & $\mathbf{0 . 1 4 1} ; 1 ; 1.6$ & $\mathbf{0 . 1 0 0} ; 8 ; 1.1$ & $\mathbf{0 . 0 2 6} 8 ; 0.3$ \\
L-UVB & $\mathbf{0 . 0 9 0} ; 2 ; 1.0$ & $\mathbf{0 . 3 4 9} ; 5 ; 3.9$ & $\mathbf{0 . 4 8 0} ; 6 ; 5.4$ & $\mathbf{0 . 1 2 2} ; 10 ; 1.4$ & $\mathbf{0 . 0 2 9} ; 25 ; 0.3$ & $\mathbf{0 . 0 1 0} ; 22 ; 0.1$ \\
H-UVB & $\mathbf{0 . 0 9 0} ; 2 ; 1.0$ & $\mathbf{0 . 3 4 9} ; 10 ; 3.9$ & $\mathbf{0 . 1 2 5} ; 2 ; 1.4$ & $\mathbf{0 . 1 1 5} ; 13 ; 1.3$ & $\mathbf{0 . 0 4 4} ; 13 ; 0.5$ & $\mathbf{0 . 0 1 8} ; 13 ; 0.2$ \\
\hline
\end{tabular}




\section{The transience and fate of the $\mathrm{DMSP}_{t}$ peak in Expt 1}

DMSP $_{\mathrm{t}}$ concentrations in Expt 1 declined after $\mathrm{d}_{2}$ almost as rapidly as they had increased. Between $d_{2}$ and $\mathrm{d}_{4}$, average losses of $\mathrm{DMSP}_{\mathrm{t}}$ were 42.1 (PAR), 50.0 (UVA), 39.2 (L-UVB) and 42.4 (H-UVB) nmol $\mathrm{l}^{-1}$ $\mathrm{d}^{-1}$. Phytoplankton are the ultimate source of bacterial substrates (Shiah \& Ducklow 1997) and our results show that bacterial production was very high in conjunction with significant increases in phytoplankton abundances by the end of Expt 1 (see section 'Experiment 1 ' in 'Results'). Comparatively high rates of bacterial production are not unusual in the Davis coastal region (see Pearce et al. 2007). The high $d_{14}$ rates of bacterial production observed probably resulted from both nutrient-replete conditions and the initial $200 \mu \mathrm{m}$ screening of metazooplankton grazers, which allowed large quantities of phytoplankton biomass to build up, increasing substrate availability. DMS/P related compounds may have constituted part of this substrate build-up; however, the initial increase and decline in $\mathrm{DMSP}_{\mathrm{t}}$ and the high bacterial production rates at $\mathrm{d}_{14}$ are unlikely to have been related due to the temporal gap that existed between the 2 events. Merzouk et al. (2008) examined uptake of DMS/P compounds by bacteria in a declining spring bloom in the NW Atlantic and found that bacteria can respond rapidly to transient pulses in dissolved DMSP. However, the increased DMSP uptake observed declined rapidly within days of the dissolved DMSP pulse, presumably as availability of other S-containing compounds lessened the importance of DMSP. In Expt 1, the main increase in total bacteria coincided with increasing phytoplankton biomass after $d_{7}$, not between $d_{2}$ and $d_{4}$, when the $\mathrm{DMSP}_{\mathrm{t}}$ peak declined most rapidly, suggesting that DMSP $_{\mathrm{t}}$ loss between $\mathrm{d}_{2}$ and $\mathrm{d}_{4}$ was not dominated by bacterial uptake (Table 2, Fig. 2).

Recently, Asher et al. (2011) found high concentrations and turnover rates of DMS, DMSP and DMSO in Antarctic sea ice in the Amundsen and Ross Seas during austral summer (December-January). Interestingly, these authors found that DMS production was dominated by reduction of DMSO in brine samples, as opposed to cleavage of DMSP, and that rapid redox cycling between DMS and DMSO contributed to the transience of DMS pools in the SIZ. These findings are related to the anti-oxidant hypothesis of Sunda et al. (2002), whose laboratory experiments confirmed that hydroxide radicals oxidise DMS to DMSO, MSNA and methane sulfonate (MSA), while DMSP was also quantitatively oxidised to MSNA and MSA, with DMSO as the reactive intermediate. However, redox cycling between DMS and DMSO could only have had a significant impact in Expt 1 if DMS resulting from the $\mathrm{DMSP}_{\mathrm{t}}$ peak was rapidly converted to DMSO (which was not analysed). We observed comparatively small increases in DMS between $\mathrm{d}_{2}$ and $\mathrm{d}_{4}$ that may have been related to DMSP cleavage prior to conversion of DMS to DMSO; however, this does not satisfactorily explain the rapid loss of such high DMSP $_{\mathrm{t}}$ concentrations. It seems likely that after the initial $\mathrm{DMSP}_{\mathrm{t}}$ production that occurred between $\mathrm{d}_{0}$ and $d_{2}$, the DMSP decline was due to conversion of DMSP to not only DMS but also other reactive and final products (such as DMSO and MSNA), as noted by Sunda et al. (2002) and in part observed by Asher et al. (2011). This model of DMS as only one of a number of reactive intermediates in the anti-oxidative process may explain the lack of accumulation of significant amounts of DMS at any point in Expt 1, as well as the rapid decline in $\mathrm{DMSP}_{\mathrm{t}}$.

\section{Expt 1 and 2 comparison - low- versus high-light-acclimated communities}

$\mathrm{DMSP}_{\mathrm{t}}$ concentrations from Expt 2 suggest that rapid synthesis of DMSP for photo-protective/antioxidation reasons was not necessary during the initial exposure period, as $\mathrm{DMSP}_{\mathrm{t}}$ increased in a steady and linear fashion. DMS concentrations remained low throughout Expt 2, either through minimal production of DMS, bacterial consumption of DMS and/or rapid oxidative conversion of DMS as noted by Asher et al. (2011).

Chl a concentrations increased in all treatments during the first days of exposure of Expt 2, yet most phytoplankton group abundances did not increase and in many cases declined (including the dominant cryptophyte species). This contrasts with what occurred in the first days of exposure of Expt 1, where phytoplankton abundances remained generally stable, or in a few cases (most notably Phaeocystis antarctica) increased despite a small (relative to later concentrations) decline in chl a concentrations. Thus initial changes in chl $a$ in both experiments appeared to largely depend on physiological changes rather than changes in abundances. In Expt 1, photobleaching of pigments including chl a due to the sudden exposure to high light may have contributed to the observed chl a decline (Arrigo et al. 2010). Thomson et al. (2008) observed small initial declines in POC in some treatments of Expt 1, suggesting that cell death and lysis probably also contributed to the 
chl a decline. In Expt 2, the cause of the increase in cell-specific chl a content is more difficult to determine. Cell-specific chl a content increases have been observed in phytoplankton moving from higher to lower light climates (Falkowski \& LaRoche 1991, Arrigo et al. 2010). This is unlikely to have been the case in Expt 2. While phytoplankton in Expt 2 were probably acclimated to a higher light climate than in Expt 1 (the sea ice edge was closer and leads, cracks and advection had increased; see Thomson et al. 2008), it is unlikely moving to the full irradiance tanks would have rendered the community comparatively underexposed. Alternatively, the breaking up of sea ice prior to the collection of phytoplankton in Expt 2 may have resulted in the exposure of phytoplankton cells to random and extreme light changes (from under ice to open water). The cells may have maintained low chl $a$ levels as a coping mechanism for those sudden periods of exposure to open-water irradiances. Once exposed to a more stable light climate in the minicosm tanks, the cells then increased their levels of chl a.

The interpretation of the data presented here would benefit greatly from further study to confirm or revoke these findings. Methods have progressed in the years since this data was first collected, and more accurate assessments of DMS and DMSP cycling are now possible. This study would also benefit from duplication of the minicosm system/treatments, allowing errors to be assigned to the measured variables. However, our results showed that the initial large increase in DMSP occurred in all treatments. Expt 1 showed high variability between triplicate samples (particularly in the initial days of exposure) compared with Expt 2 (see legends to Figs. 2 \& 3), probably as a result of the rapid changes in cell growth and metabolism that were occurring. Unfortunately, given the size and complexity of the minicosm system, replication of treatments was not financially or logistically possible.

\section{Summary}

The phytoplankton community composition of the 2 experiments was similar compared with a third diatom-dominated experiment that was conducted after the sea ice had disappeared (see Thomson et al. 2008). Despite this similarity, our observations demonstrate the vastly different DMSP production responses that phytoplankton communities initiate due to differences in community light history. In the SIZ, extremely low-light acclimated cells can be exposed to surface irradiances within hours, causing rapid photo-damage. Phytoplankton have developed means to avoid, sustain and repair damage, such as the quenching of toxic photo-products with antioxidants (Davidson 2005). Expt 1 shows that DMSP production can be upregulated very rapidly, probably to counteract the effects of sudden exposure to surface irradiances (Sunda et al. 2002). This kind of response is rare, transient, occurs over time scales as short as hours, and is dependent on both community light history and rapid light increases.

The SIZ is a highly productive environment, although shallow mixed depths and rapid sea ice breakout in spring means that species need to tolerate high irradiances (Kirst \& Weincke 1995). Phaeocystis sp. is known to be a prolific DMSP producer (Gibson et al. 1990) and our observations suggest that $P$. antarctica was most likely responsible for the bulk of the DMSP ${ }_{\mathrm{t}}$ produced in the first $2 \mathrm{~d}$ of Expt 1, probably for anti-oxidation. The DMSP was then rapidly excreted and/or converted into other related compounds as acclimation progressed. This process is analogous to observations from the Northern Hemisphere of another prolific DMSP producer, Emiliania huxleyi. Blooms of E. huxleyi are also frequently associated with shallow mixed layer depths, high irradiances and an ability to rapidly cycle DMS/ P/O on time scales similar to those necessary for photo-acclimation (Archer et al. 2010).

The short duration of the $\mathrm{DMSP}_{\mathrm{t}}$ peak in Expt 1 may explain why this has not previously been observed in wild communities. However, conditions analogous to those during Expt 1 (rapid exposure to surface irradiances) can occur in protected parts of the Antarctic coastline. This may result in a sudden increase in $\mathrm{DMSP}_{\mathrm{t}}$ concentrations in wild communities. Our results do not suggest that these events would result in appreciable DMS production during late spring, as the DMSP produced may be rapidly converted or consumed via other processes.

Acknowledgements. This project was supported by the Australian Government's Cooperative Research Centres Program (Antarctic Climate \& Ecosystems CRC) and Australian Antarctic Division AAS grants 40, 2100, 1172 and 757. We thank S. Wright for analysis assistance.

\section{LITERATURE CITED}

Andreae MO (1993) The influence of tropical biomass burning on climate and the atmospheric environment. In: Oremland RS (ed) Biogeochemistry of global change: radiatively active trace gases. Chapman \& Hall, New York, NY, p 113-150 
Andreae MO, Crutzen PJ (1997) Atmospheric aerosols: biogeochemical sources and role in the atmospheric chemistry. Science 276:1052-1058

Archer SD, Ragni M, Webster R, Airs RL, Geider RJ (2010) Dimethyl sulfoniopropionate and dimethyl sulphide production in response to photoinhibition in Emiliania huxleyi. Limnol Oceanogr 55:1579-1589

Arrigo KR, Mock T, Lizotte MP (2010) Primary producers in sea ice. In: Thomas DN, Deickman GS (eds) Sea ice. Wiley-Blackwell, Oxford, p 283-325

Asher EC, Dacey JWH, Mills MM, Arrigo KR, Tortell PD (2011) High concentrations and turnover rates of DMS, DMSP and DMSO in Antarctic sea ice. Geophys Res Lett 38:L23609, doi:10.1029/2011GL049712

> Ayers GP, Ivey JP, Gillett RW (1991) Coherence between seasonal cycles of dimethylsulphide, methanesulfonate and sulphate in marine air. Nature 349:404-406

- Bates TS, Charlson RJ, Gammon RH (1987) Evidence for the climatic role of marine biogenic sulphur. Nature 329: 319-321

Bell RT (1993) Estimating production of heterotrophic bacteria via incorporation of tritiated thymidine. In: Kemp PF, Sherr PF, Sherr EB, Cole JJ (eds) Handbook of methods in aquatic microbial ecology. Lewis, Boca Raton, FL, p 495-503

- Belviso S, Caniaux G (2009) A new assessment in North Atlantic waters of the relationship between DMS concentration and the upper mixed layer solar radiation dose. Glob Biogeochem Cycles 23:GB1014, doi:10.1029/ 2008GB003382

> Charlson RL, Lovelock JE, Andreae MO, Warren SG (1987) Oceanic phytoplankton, atmospheric sulfur, cloud albedo and climate. Nature 326:655-661

Curran MAJ, Jones GB (2000) Dimethylsulfide in the Southern Ocean: seasonality and flux. J Geophys Res 105 (D16):20451-20459

Curran MAJ, Jones GB, Burton H (1998) Spatial distribution of dimethylsulfide and dimethylsulfoniopropionate in the Australasian sector of the Southern Ocean. J Geophys Res 103(D13):16677-16689

Davidson AT (2005) Effects of ultraviolet radiation on microalgal growth, survival and production. In: Rao DVS (ed) Algal cultures, analogues of blooms and applications. Science Publishers, Plymouth, p 715-767

Davidson AT, Marchant HJ (1992) The biology and ecology of Phaeocystis (Prymnesiophyceae). In: Round FE, Chapman DJ (eds) Progress in phycological research, Vol 8. Biopress, Bristol, p 1-46

Davidson AT, Marchant HJ (1994) The impact of ultraviolet radiation on Phaeocystis and selected species of Antarctic marine diatoms. In: Weiler CS, Penhale PA (eds) Ultraviolet radiation in Antarctica: measurement and biological effects. Antarctic Research Series 62. American Geophysical Union, Washington, DC, p 160-187

> Davidson AT, van der Heijden A (2000) Exposure of natural Antarctic marine microbial assemblages to ambient UV radiation: effects on bacterioplankton. Aquat Microb Ecol 21:257-264

del Valle D, Slezak D, Smith CM, Rellinger AN, Kieber DJ, Kiene RP (2011) Effect of acidification on preservation of DMSP in seawater and phytoplankton cultures: evidence for rapid loss and cleavage of DMSP in samples containing Phaeocystis sp. Mar Chem 124:57-67

> Delille D (2004) Abundance and function of bacteria in the Southern Ocean. Cell Mol Biol 50:534-551
Derevianko GJ, Deutsch C, Hall A (2009) On the relationship between ocean DMS and solar radiation. Geophys Res Lett 36:L17606, doi:10.1029/2009GL039412

Falkowski PG, LaRoche J (1991) Acclimation to spectral irradiance in algae. $\mathrm{J}$ Phycol 27:8-14

Galí M, Saló V, Almeda R, Calbet A, Simó R (2011) Stimulation of gross dimethylsulfide (DMS) production by solar radiation. Geophys Res Lett 38:L15612, doi:10.1029/2011 GL048051

> Gibson JAE, Garrick RC, Burton HR, McTaggart AR (1990) Dimethyl sulphide and the alga Phaeocystis pouchetii in Antarctic waters. Mar Biol 104:339-346

Gibson JAE, Swadling KM, Burton HR (1997) Interannual variation in the dominant phytoplankton species and biomass near Davis station, East Antarctica. Proc NIPR Symp Polar Biol 10:77-89

> Heil P (2006) Atmospheric conditions and fast ice at Davis, East Antarctica: a case study. J Geophys Res 111:C05009, doi:10.1029/2005JC002904

Helbling EW, Villafañe V, Holm-Hansen O (1994) Effects of ultraviolet radiation on marine phytoplankton photosynthesis with particular attention to the influence of mixing. In: Weiler CS \& Penhale PA (eds) Ultraviolet radiation in Antarctica: measurements and biological effects. Antarctic Research Series 62. American Geophysical Union, Washington, DC, p 207-228

Jeffrey SW (1997) Preparation of chlorophyll standards. In: Jeffrey SW, Mantoura RFC, Wright SW (eds) Phytoplankton pigments in oceanography: guidelines to modern methods. UNESCO Publishing, Paris, p 207-238

Kiene RP, Slezak D (2006) Low dissolved DMSP concentrations in seawater revealed by small-volume gravity filtration and dialysis sampling. Limnol Oceanogr Methods 4: 80-95

Kirst GO, Weincke C (1995) Ecophysiology of polar algae. J Phycol 31:181-199

Kirst GO, Thiel C, Wolff H, Nothnagel J, Wanzek M, Ulmke R (1991) Dimethylsulfoniopropionate (DMSP) in ice-algae and its possible biological role. Mar Chem 35:381-388

> Lebaron P, Parthuisot N, Catala P (1998) Comparison of blue nucleic acid dyes for flow cytometric enumeration of bacteria in aquatic systems. Appl Environ Microbiol 64: $1725-1730$

Lizotte M, Levasseur M, Michaud S, Scarratt MG and others (2012) Macroscale patterns of the biological cycling of dimethylsulfoniopropionate (DMSP) and dimethylsulfide (DMS) in the Northwest Atlantic. Biogeochemistry 110: 183-200

Menden-Deuer S, Lessard EJ (2000) Carbon to volume relationships for dinoflagellates, diatoms and other protist plankton. Limnol Oceanogr 45:569-579

Merzouk A, Levasseur M, Scarratt M, Michaud S, Lizotte M, Rivkin RB, Kiene RP (2008) Bacterial DMSP metabolism during the senescence of the spring diatom bloom in the Northwest Atlantic. Mar Ecol Prog Ser 369:1-11

> Niyogi KK (1999) Photoprotection revisited: genetic and molecular approaches. Annu Rev Plant Physiol Plant Mol Biol 50:333-359

Nunez M, Davidson AT, Michael K (2006) Modelled effects of ambient UV radiation on a natural Antarctic marine microbial community. Aquat Microb Ecol 42:75-90

Pearce I, Davidson AT, Bell EM, Wright S (2007) Seasonal changes in the concentration and metabolic activity of bacteria and viruses at an Antarctic coastal site. Aquat Microb Ecol 47:11-23 
Quinn PK, Bates TS (2011) The case against climate regulation via oceanic phytoplankton sulphur emissions. Nature 480:51-56

Servais P, Courties C, Lebaron P, Troussellier M (1999) Coupling bacterial activity measurements with cell sorting by flow cytometry. Microb Ecol 38:180-189

Shiah FK, Ducklow HW (1997) Bacterioplankton growth responses to temperature and chlorophyll variations in estuaries measured by thymidine:leucine incorporation ratio. Aquat Microb Ecol 13:151-159

Smolskaia I, Nunez M, Michael K (1999) Measurements of erythemal irradiance near Davis station, Antarctica: Effect of inhomogeneous surface albedo. Geophys Res Lett 26:1381-1384

SooHoo JB, Palmisano AC, Kottmeier ST, Lizotte MP, SooHoo SL, Sullivan CW (1987) Spectral light absorption and quantum yield of photosynthesis in sea ice microalgae and a bloom of Phaeocystis pouchetii from McMurdo Sound, Antarctica. Mar Ecol Prog Ser 39:175-189

Stefels J, van Leeuwe MA (1998) Effects of iron and light stress on the biochemical composition of Antarctic Phaeocystis sp. (Prymnesiophyceae) I. Intracellular DMSP concentrations. J Phycol 34:486-495

Stefels J, Steinke M, Turner S, Malin G, Belviso S (2007) Environmental constraints on the production and removal of the climatically active gas dimethylsulphide (DMS) and implications for ecosystem modelling. Biogeochemistry 83:245-275

Sunda W, Kieber DJ, Kiene RP, Huntsman S (2002) An antioxidant function for DMSP and DMS in marine algae. Nature 418:317-320

Tang KW, Smith WO, Shields AR, Elliott DT (2009) Survival and recovery of Phaeocystis antarctica (Prymnesiophyceae) from prolonged darkness and freezing. Proc R Soc Lond B Biol Sci 276:81-90

Editorial responsibility: Douglas Capone, Los Angeles, California, USA
Thomas DN, Dieckmann GS (2002) Antarctic sea ice-a habitat for extremophiles. Science 295:641-644

Thomson PG, McMinn A, Keissling I, Watson M, Goldsworthy PM (2006) Composition and succession of dinoflagellates and chrysophytes in the upper fast ice of Davis station, East Antarctica. Polar Biol 29:337-345

> Thomson PG, Davidson AT, Cadman N (2008) Temporal changes in the effects of ambient UV radiation on natural communities of Antarctic marine protists. Aquat Microb Ecol 52:131-147

Toole DA, Slezak D, Kiene RP, Kieber DJ, Siegal DA (2006) Effects of solar radiation on dimethylsulfide cycling in the western Atlantic Ocean. Deep-Sea Res Part I 53: $136-153$

Trevena AJ, Jones GB (2006) Dimethylsulfide and dimethylsulfoniopropionate in Antarctic sea ice and their release during sea ice melting. Mar Chem 98:210-222

Trodahl HJ, Buckley RG (1989) Ultraviolet levels under sea ice during the Antarctic spring. Science 245:194-195

> Vallina SM, Simo R (2007) Strong relationship between DMS and the solar radiation dose over the global surface ocean. Science 315:506-508

> Vincent WF, Roy S (1993) Solar ultraviolet-B radiation and aquatic primary production: damage, protection and recovery. Environ Rev 1:1-12

- Woodhouse MT, Mann GW, Carslaw KS, Boucher O (2013) Sensitivity of cloud condensation nuclei to regional changes in dimethyl-sulphide emissions. Atmos Chem Phys 13:2723-2733

> Wright SW, Thomas DP, Marchant HJ, Higgins HW, Mackey MD, Mackey DJ (1996) Analysis of phytoplankton of the Australian sector of the Southern Ocean: comparisons of microscopy and size frequency data with interpretations of pigment HPLC data using the 'CHEMTAX' matrix factorisation program. Mar Ecol Prog Ser 144:285-298

Submitted: December 27, 2012; Accepted: September 30, 2013 Proofs received from author(s): November 27, 2013 